\title{
Małgorzata Rybicka*
}

\section{CULTURAL AND SETTLEMENT CHANGES IN THE SECOND HALF OF THE $4^{\text {TH }}$ MILLENNIUM BC IN THE AREA BETWEEN THE BUG, DNIESTR AND PRUT RIVERS}

\begin{abstract}
Rybicka M. 2020. Cultural and settlement changes in the second half of the $4^{\text {th }}$ Millennium $\mathrm{BC}$ in the area between the Bug, Dniestr and Prut rivers. Sprawozdania Archeologiczne 72/1, 63-85.

The literature on the subject emphasizes the migration of the CII Tripolye culture from south to north. A particularly interesting issue is the presence of imports of the Funnel Beaker Culture in the environment of the Moldovan Brînzeni group, and especially from which regions they come. Volhynia was suggested to be the area from which these materials came, because along with ceramics of the Funnel Beaker Culture in the Brînzeni group, objects of Volhynian raw material were also discovered in the literature.

The discovery of a stable Funnel Beaker culture settlement north of the Brînzeni group, in Kotoryny near Zhydachiv, has raised a number of questions about this problem. Also, the identification in the Western Volhynian region of the Tripolye Culture settlement in Novomalin-Podobanka near Ostrog, from which vessels with the characteristics of the Brînzeni group and Funnel Beaker Culture are known, shows that clarification of the relationships between South and North Tripolye Culture communities requires further research.
\end{abstract}

Keywords: Funnel Beaker culture, Tripolye culture, Western Ukraine, Brînzeni group, Neolithic Received: 30.01.2020; Revised: 12.05.2020; Accepted: 10.06.2020

\footnotetext{
* Institute of Archaeology Rzeszów University, Moniuszki st. 10, 35-015 Rzeszów, Poland; mrybicka@interia.eu
} 


\section{INTRODUCTION}

The second half of the $4^{\text {th }}$ Millennium BC was a time of disintegration of the classical settlement system of the Tripolye culture (TC), which resulted in economic changes of this unit (e.g. Kruc 1994; Videyko 2007; Harper et al. 2019). Many researchers claim that these events were strongly affected by climate change (Harper 2013), which resulted in steppe formation (Makohonienko 2011). In the descriptions of economic changes in the TC, the matter of food acquisition is vaguely discussed in the context of demographic change (Harper et al. 2019; Diachenko 2019). In the period between 3600-3000 BC, the greatest emphasis is placed on the transition from agriculture to pastoral farming.

Such a general assessment of changes characterizes the Lengyel-Polgar, Funnel Beaker culture (FBC) and Baden culture communities that settled the uplands and lowlands between the Oder and Bug rivers in the $4^{\text {th }}$ Millennium BC (Kruk and Milisauskas 1999; Pelisiak 2018). In palynological diagrams (Kruk 1980) with accurate dating (Pelisiak et al. 2006; Grygiel 2008; Wacnik and Rybicka 2012; Szmyt 2013), the changes are marked by evidence of human exploitation of the environment in a variety of ways. Economic changes in "western" communities correlate with the changes in settlement models (Kruk 1980; Kruk and Milisauskas 1999). Instead of settling lowlands, as was done by Lengyel-Polgar communities that were actively farming, the FBC communities started to settle in higher and drier areas used for agricultural purposes, and began to use the farming method known as slash-and-burn agriculture. At the end of the $4^{\text {th }}$ millennium, the significance of animal husbandry in the Funnel Beaker-Baden and Globular Amphora Culture communities also increases (Kruk 1980; Szmyt 2013).

The reasons for economic changes within the TC and, for example, in the FBC are explained in different ways. In the first case, the main reason seems to be climate change (Harper 2017), whereas in the second, the anthropogenic impact on the environment is considered (Kruk 1980; Kruk et al. 1996; Pelisiak et al. 2006). In Eastern Europe, we may observe climate change not in a regional, but a macro scale (Harper 2017). This shows that in order to understand the phenomenon and the dynamics of changes in the TC, regional studies that are empirical and analogous to those carried out in Talianky (Harper 2012) should be performed. Currently, it is not possible to describe the dynamics of changes of economic systems used by communities of the TC and western cultures (Lengyel-Polgar and FBC) in the areas from North Moldova to Western Volhynia. This is the result of a lack of studies on economic and settlement patterns that incorporate archaeozoological and archaeobotanical analyses. Moreover, it is not always possible to precisely date the appearance of different cultural groups of the TC (Rybicka 2017; Harper et al. 2019).

According to many researchers, socio-cultural changes of the TC were visibly influenced by migrations of people (e.g from the Tomaschivka group: Harper et al. 2019). The same reason is given to explain the appearance of groups representing the early CII stage, with the characteristics of the Moldavian Brînzeni group, in Volhynia (Dergachev 1980; Tkachuk 
1998; Rizhov 2007), and synchronized with Troyaniv group. Aleksandr Diachenko and Aleksandr Kirilenko $(2016,129)$ wrote “... Considering the above arguments, one can agree with the opinion of S. Rizhov about the settlements left by the migrants from Brînzeni as the earliest in the studied region...”. The nature of settlements like Lystvyn-Holishyv, which represent communities with characteristics of the Moldavian Gordineşti group in Western Volhynia, is debatable (Pozikhovskyj 2019b; Verteletskyi 2019a; 2019b). Some researchers claim that the appearance of these groups is a result of influences of the youngest TC group (Kruts and Ryzhov 2000, 108). The question is whether the occurrence of these groups may be the consequence of migrations from the South to the North. According to M. Videiko $(2000,67)$, at that time "....Migratory processes, mainly of the population of the Carpathian Basin, resulted in the appearance of the Gordineşti, Troyaniv cultural types. Their subsequent translocation to the east gave rise to the Sofievka type...”. In the territory of Western Volhynia, we may observe the presence of western groups or their characteristics visible in pottery of the TC (e.g. Rybicka 2015; 2017; Diaczenko et al. 2016).

It is difficult to present the set of stylistic features of TC ceramics, especially from the early CII stage (Markevich 1981; Diachenko and Kirilenko 2016; Rybicka 2017), which hampers the evaluation of changes at the time of the CII stage of the TC. With regard to studies carried out under the auspices of the project, "Between the East and the West. Dynamic of Social Changes from the Eastern Carpathians to the Dnieper in $4^{\text {th }}-$ beginning of $3^{\text {rd }}$ mil. BC" (Diachenko et al. 2019), there will be an attempt to specify the changes that have occurred in the explored area in the second half of the $4^{\text {th }}$ Millennium BC, in the context of changes in ceramic decoration and new radiocarbon dating. Particular attention will be paid to the importance of migration, direct contacts between various groups, innovations, imitation and unification observed in the ceramic styles of communities living in the studied region.

\section{THE SOCIAL AND CULTURAL SITUATION IN THE SOUTH AND NORTH PERIPHERIES OF THE TC IN THE AREA FROM MOLDOVA TO WESTERN VOLHYNIA}

\section{The beginnings of stage $\mathrm{Cll}$ of the TC}

In the second half of the $4^{\text {th }}$ Millennium, the Brînzeni cultural group, occupying northern Moldova and the areas by the Dniester, in the context of the TC, was characterized by medium-size settlements located in hilly terrain (from a few to several hectares) with different elevations (Fig. 1: A; Markevich 1981; Król 2019). Moldovan settlements of this group in Brînzeni, site III, and in Costeşti, site IV, were built on an oval plan with a partly built-up maidan. There were about 30 houses. It is difficult to specify whether all buildings were of a social character, or whether, perhaps, there were areas intended for agriculture and rituals. 

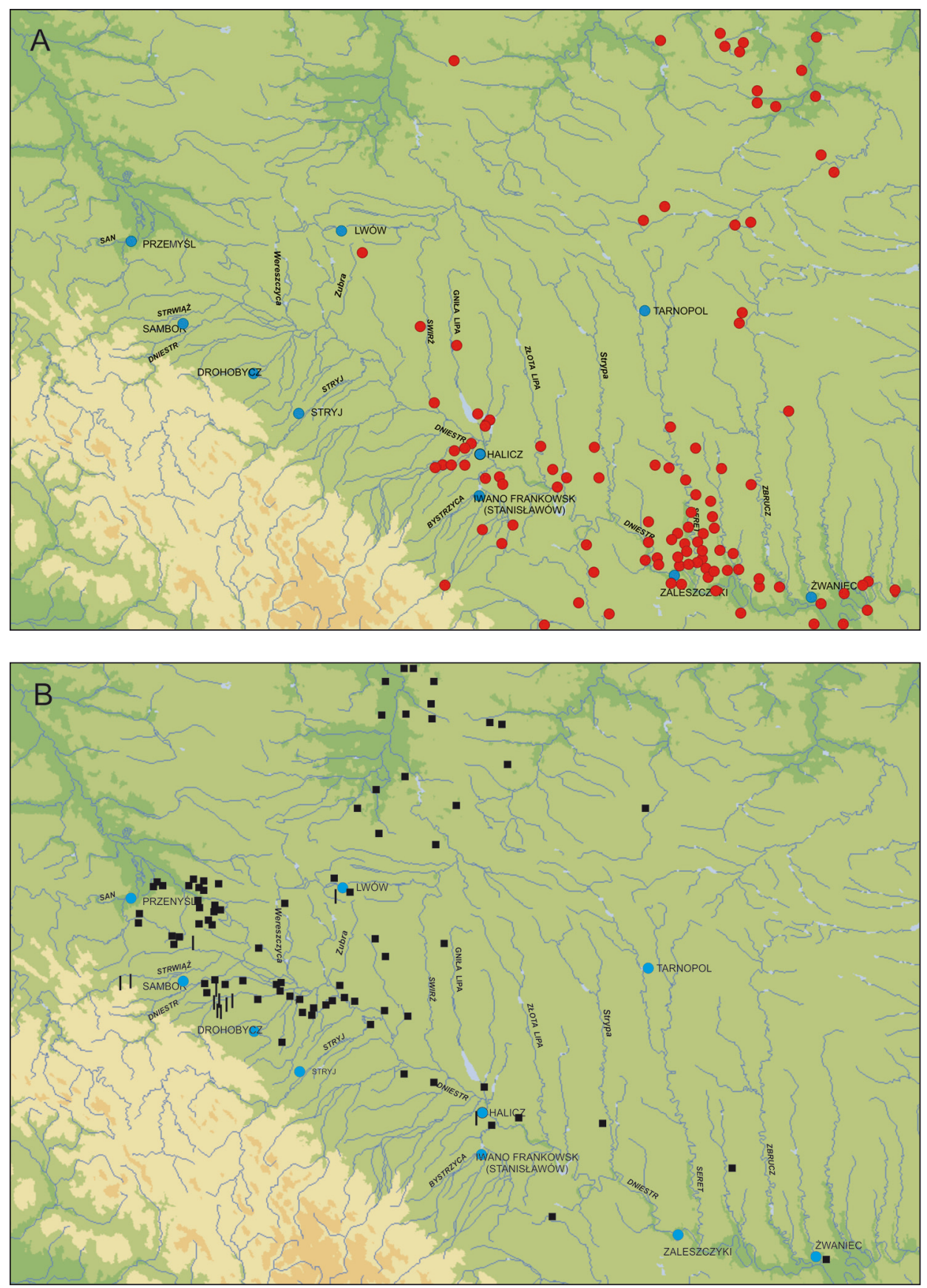

Fig. 1. Settlements of the Cll stage of the Tripolye culture (A) and the Funnel Beaker culture (B) (acc. to Pelisiak 2005) 
According to V. Markevich (1981, 136), the settlers were farming cereals (various species of wheat, and barley and millet?) and legumes (peas), using tools made of an imported Volhynian material. The main livestock were cattle, sheep, horses (mobile species), whereas the role of swine was not very significant (Markevich 1981, 136). The basic consumption products were domesticated species.

Communities of that group had strong connections with the FBC, which is exemplified by the so-called imports of FBC ceramics from settlements in Brînzeni (Markevich 1981; Movsha 1985), Costeşti IV (Markevivh 1981), and Zhvaniets (Movsha 1985), found within houses. The issue of relations between the FBC and the TC has been broadly discussed in recent times (Rybicka 2017). The available dating for sites in Brînzeni and Costeşti IV are younger than radiocarbon dates obtained for settlements of the FBC where imports from the Brînzeni group were identified (Włodarczak 2006; Rybicka 2017). The observed asynchronicity clearly shows that the accepted time frames for the Brînzeni group are questionable (Rybicka 2017).

The presence of imports of the FBC is an indicator of direct contact between communities of the two cultures. However, the provenience of the $\mathrm{FBC}$ vessels identified at the aforementioned sites, in which objects of Volhynian raw material also have a significant share, is debatable. Assuming that the import of tools made of such flint are from Western Volhynia, where FBC and syncretic ceramics have been found in settlements of the TC (Rybicka 2015; Rybicka and Diachenko 2016; Rybicka 2017), it may be suggested that, together with Volhynian material, FBC ceramics reached the area of the Brînzeni group. However, the interpretation of that fact is debatable. Therefore, it is worth taking a closer look at the cultural situation in the territory between Volhynia and northern Moldova.

As a result of recent studies, the upper Dniester in the area of Zhydachiv has been set out as the south-eastern border of the west Ukrainian type of FBC. The southernmost settlement of the FBC in this territory is in Kotoryny, Grodzisko III, in the region of Zhydachiv (Harmatowa et al. 2013; Hawinskyj et al. 2013). The distance between the abovementioned settlement and the Brînzeni group is about $250 \mathrm{~km}$ (Fig. 1: A; 1: B). As in Western Volhynia (Rybicka 2017), it may be suggested that cultural interactions on the border of the FBC and the TC were strongly visible, and communities of the Brînzeni group had direct contact with people of the $\mathrm{FBC}$; thus, the pottery discovered in settlements of the Brînzeni group could have originated in the FBC (Rybicka 2017). Is it possible that together with FBC vessels, the Volhynian material could have reached the Brînzeni group? It is difficult to specify the original region of the Volhynian material, as the of "Turonian" flint (Konopla 1998; 2013) discovered in the trans-Dniester region is macroscopically similar and hard to distinguish from the kind excavated in Western Volhynia (Konopla 1998). Moreover, there is no information about any settlement functioning in the area of the upper Dniester that could be a centre of distribution of Volhynian flint items within the Brînzeni group, as in the case of the FBC trading post identified in Gródek by the Bug river (Balcer 1983; Diachenko and Rybicka 2019). The FBC settlement functioning in the above- 
mentioned region serves as a distribution centre for items made of Volhynian flint to south-eastern and eastern groups of this culture (Balcer 1983; Diachenko and Rybicka 2019). Yet another possible interpretation of the origin of Volhynian material within the range of the Brînzeni group, is as an import from Western Volhynia. It is hard to say whether the communities of the Brînzeni group received finished, semi-finished or processed products made of Volhynian material in settlements of that group (Markevich 1981).

The features of the Brînzeni group have been shall be recorded in Volhynia (Kruts and Ryzhov 2000), including the Ostrog area, where they can be observed in settlements like Khoriv and Novomalin-Podobanka (Diachenko and Kirilenko 2016). There are a few possibilities that may explain their appearance in the mentioned region:

- migration of some part of the population or a small group of people (Dergachev 1980, 132; Tkachuk 1998; Rizhov 2007; Diachenko and Kirilenko 2016),

- features of the Brînzeni group appear in Volhynia due to the trade or exchange of Volhynian material (Dergachev 1980, 133).

Why did some segment of the Brînzeni group decide to migrate to the north, to Volhynia? What could have been the impetus and when did it happen?

Based on the data obtained in the area of northern Moldova and Transnistria (Fig. 1: A; Król 2019), it can be claimed that occupation of the Brînzeni group was not very intensive, and settlements were relatively small. No more than 30 houses were identified in Brînzeni and Costeşti, which suggests a small number of inhabitants. The authors of the published study on the relationship between the state of the environment and the population size presented the assumption that the suitability of a given habitat for colonization is a function of the availability of resources, while the usefulness decreases as population density increases (Harper et al. 2019). Taking into account the aforementioned data, migration of Brînzeni groups was not a consequence of the increasing number of people or an environmental crisis caused by anthropopresion, in which it was not possible to carry out agricultural activities. According to T. Harper (2017), between 3825-3650 BC, the climate cooldown in Moldova (and elsewhere) caused changes in settlement and economic systems in favour of a more mobile lifestyle, whereas more convenient economic conditions appeared around 3300 BC (Harper et al. 2019). On the basis of radiocarbon dating, benchmark settlements of the Brînzeni group may be dated to the period between 3400-3100 BC (Fig. 2: A), whereas settlements like Novomalin-Podobanka may date to between 3500-3300 BC (Rybicka 2017). The latter date range conforms well to the chronology of settlements of the eastern and south-eastern FBC that include imports with features of the Brînzeni group (Rybicka 2017). Interesting analytical results have been found based on relations between the environment and the size of the population in Volhynia, “...where habitat suitability predictably decreases as population increases during the Neo-Eneolithic, but then increases with population during the Terminal Eneolithic and EBA transition. This may be reflective of changes in subsistence strategy accompanying the colonization of the region by populations 
belonging to the Brynzenskaya local group...” (Harper et al. 2019). In the cited work, there is no data about the settlements included in the presented analyses, and no mention of whether the sites serve as representatives for the whole Volhynian region or only for its particular sub-regions. A complicated settlement and cultural situation, relatively poor reconnaissance of the territory, and the cultural borders in this region between the western and eastern world (Rybicka 2017) are problematic for geographical and settlement analysis. Although it is possible to determine the scope of the oecumene of the FBC in Volhynia, with the left bank of the Styr River as the borderline, it is difficult to identify the size of the area occupied by previous western communities (Malice culture - MC, Lublin-Volhynian culture - LVC). The settlement strategies of these communities are well described for the occupied regions west of the Bug River (Kruk 1980; Kruk and Milisauskas 1999; Rybicka 2004; Grygiel 2008; 2016), and probably in the area by the right bank of the Bug are not much different from the strategies typical for these communities in their original territories.

A complicated settlement and cultural situation is especially observed in the area of Dubno and Ostrog (Pozikhovskiy and Samoliuk 2008; Pasterkiewicz et al. 2013; Diaczenko et al. 2016; Bardeckiy and Verteletskiy 2018). Materials of the MC, LVC, or FBC (Pozikhovskiy and Samoliuk 2008; Rybicka 2017) discovered within TC contexts, the presence of functionally differentiated remains of the TC (e.g. flint workshop; Mezhyrich), relatively high-lying permanent settlements (Ostrog-Zeman: Pozikhovskiy and Samoliuk 2008; Pozikhovskyj 2019a; Novomalin-Podobanka: Diaczenko et al. 2016), and low-lying, small settlements of particular economic functions, like Kurgany-Dubova (Diaczenko et al. 2016), show that models of settlement were diversified, and the choice of land to colonize could have been made according to the type of activities carried out there ( $c f$. Kobyliński 1988; Kruk et al. 1996). If we consider that settlements combining traditions of the TC and MC, like Ostrog-Zeman (Pozikhovskiy and Samoliuk 2008), dated to around 4000-3800 BC, were situated at both higher and lower elevations in the landscape, similar to settlements with features of the Brînzeni group (high-lying: Novomalin-Podobanka: Diachenko et al. 2016; low-lying: Mezhyrich: Pasterkiewicz et al. 2013), then it is hard to agree with the presented hypothesis (Harper et al. 2019) that colonies with features of the Brinzeni group are connected with a change of settlement and agricultural strategies - especially because these are not well recognized in either case. Nevertheless, it is worth mentioning that the period between $4000-3600 \mathrm{BC}$ is characterized by the presence of settlements combining $\mathrm{TC}$ and $\mathrm{MC}$ or LVC in this region. There is no information about colonies that are purely of the LVC or the FBC, for example. However, in case of the FBC, there is a description of a region in the area of Ostrog where relations between communities of the FBC and the TC could be observed, and which resulted in the appearance of syncretic phenomena (Rybicka 2017). Economic strategies of FBC communities in the territory between the Bug and Oder Rivers are well identified. Their typical feature is extensive slash-and-burn agriculture, when in the years between 3600-3300 BC, a significant role was played by Volhynian raw 


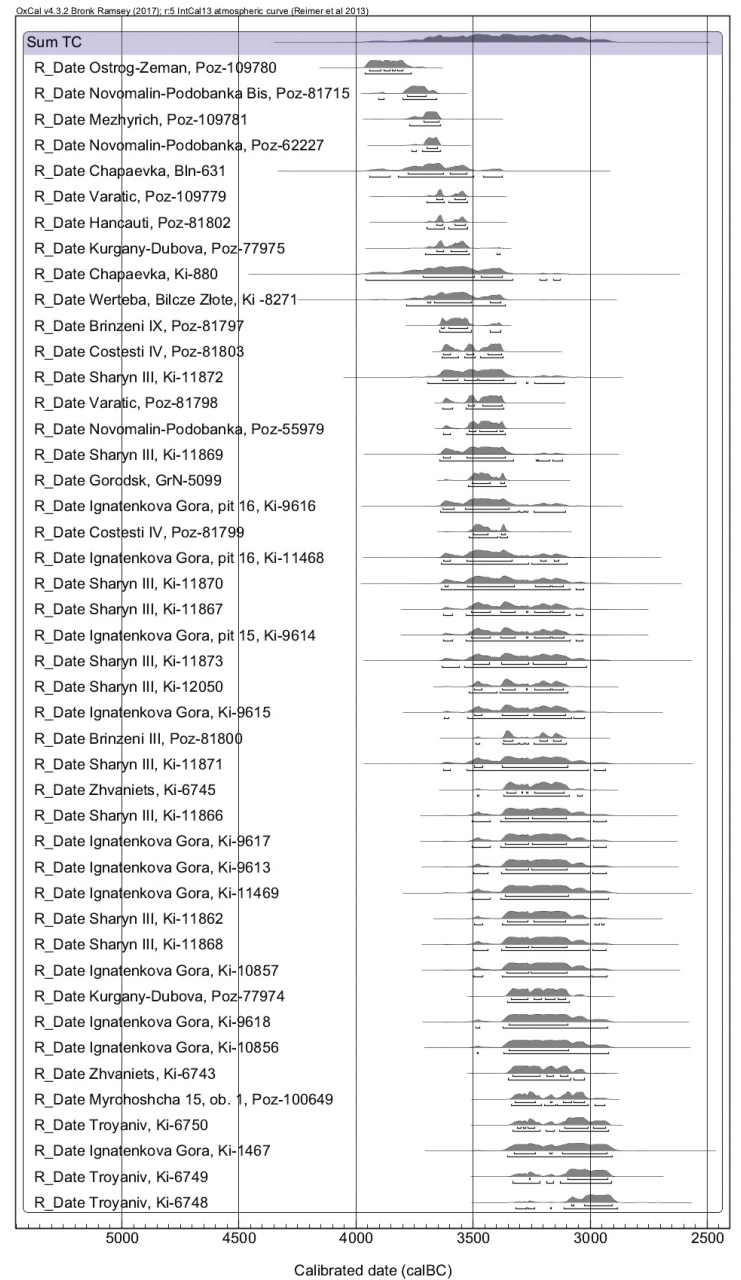

A

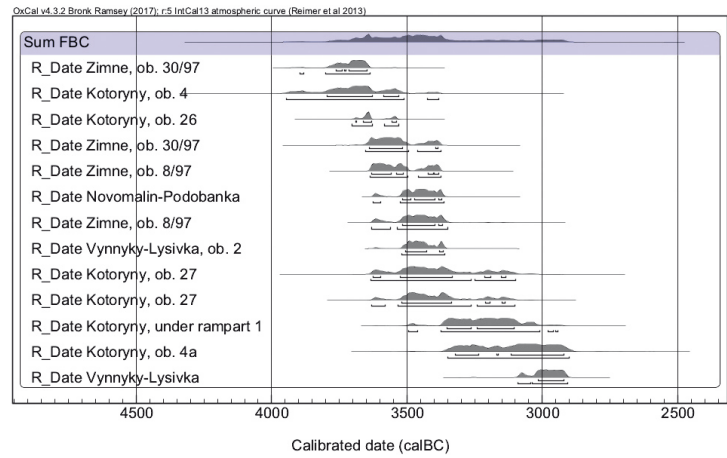

Fig. 2. Radiocarbon dates for the Tripolye culture (A) and the Funnel Beaker culture (B) from the $4^{\text {th }}$ millennium for sites between northern Moldova and Volhynia (acc. Rybicka et al. 2019) 
material (Kruk and Milisauskas 1999; Rybicka 2004; 2017; Grygiel 2016). The remains of the settlement of the FBC and the TC from Novomalin-Podobanka chronogically fit well in in this problem (Rybicka 2016b; 2017). It is difficult to determine the agricultural system of the TC in Volhynia at that time, and to tell whether the communities colonizing this region in the first half of the $4^{\text {th }}$ Millennium were actively engaged in agriculture like the communities of the Lengyel-Polgar culture, or whether there was a different kind of agricultural strategy. The change of agricultural strategy suggested by Harper, Diachenko, Rassamakin and Kennett (2019) was not necessarily the effect of a migration of people from the south, especially because those people were not representative of all features of the Brînzeni group of the TC. The migrants did not enter the unsettled area, as the land was previously inhabited by the western Polgarian communities and TC groups. It is hard to tell what the nature of the interactions between the cultures was, and how intensive the settlement of the TC was. According to A. Diachenko and A. Kirilenko $(2016,126)$ “... The pure cultural complexes of TC near Ostrog are clearly unknown. As for the possible single import from the TC in the materials of the MC, such a possibility is theoretically not excluded, especially considering the location of settlements of the BII stage to the south and east of the analyzed region...” Taking into account the presence of a pottery kiln in OstrogZeman (Pozikhovskyj 2019a) and the predominance of TC artefacts in a flint workshop in Mezhyrich, for example - dated between 3800-360o BC (Pozikhovskyi; personal communication; Fig. 2: A) - it may be assumed that the identified ceramics with Polgarian features can be treated as imported items. These facts show the continuity of colonization processes in the Ostrog region.

A good understanding of the production technology of the Volhynian flint tools characteristic for inhabitants of the settlement in Novomalin-Podobanka weakens any arguments for the migration of people from the Brînzeni group to Ostrog territory (Dobrzyński and Piątkowska 2015). A. Diachenko and A. Kirilenko $(2016,126)$ associate the tools with the second stage of settlement in the discussed region by communities with Brînzeni features. In the future, it would be desirable to compare whether the treatment method of Volhynian raw material from the workshop in Mezhyrich (Pozikhovskyi; personal communication) was analogical to the one characteristic for Novomalin-Podobanka. If the production technology is analogous, it means that information regarding the discussed matter was continuously passed from one generation to another. A. Diachenko and A. Kirilenko (2016, 129) suggested that

“...Because the migrants appeared north and east of the native range of the Brînzeni group (...) with the ready-created "package" of topographical features of settlements, interior design of houses, and ceramic complex, it is reasonable to date a large wave of emigration no earlier than in the second stage of the local group's development...". It is difficult to estimate the degree of similarity between the materials from colonies in Volhynia (i.e. Kolodyazhyn, Korzhivka-Selysko and northern Moldova - Brînzeni group); however, it is possible to assume that the observed features of the Brînzeni group are the result of a mi- 
gration of people from the south. The appearance of these people in Western Volhynia may be an effect of other cultural behaviors.

Stylistics of ceramics is another factor weakening the significance of the assumption about migration. According to A. Diachenko and A. Kirilenko (2016, 129) “... As V. Kruts and S. Ryzhov have already noted, the appearance of settlements with the characteristics of the Brînzeni group in Volhynia does not mean their ceramic complexes are identical to those of the Brînzeni group in their native area...”. Not many features characteristic of the style of the Brînzeni group (e.g. motifs of figures, narrative scenes, extensive symbolism; $c f$. Markevich 1981) were identified in the complex of Novomalin-Podobanka - currently the most distinctive settlement of the early CII stage from Western Volhynia. Only the most common features, like the motif of wolf's teeth, were distinguished ( $c f$. Verteletskiy 2016). The decoration of vessels in this collection is much different from that characteristic of the Brînzeni settlement in Zhvaniets (Movsha 1982).

If we, however, consider that settlements like Novomalin-Podobanka are the result of migrations from the south, we may ask why they do not represent the whole collection of features - for example, stylistic features of Brînzeni group - but only show the most common motifs, which do not indicate cultural identity ( $c f$. Levi-Strauss 1979). Such information undermines the concept of migration of Brînzeni communities to the north. Regarding other characteristics of the Brînzeni group, such as the manner of spatial development of the settlements, it is impossible to make such a comparison due to lack of data for Western Volhynia. Currently we cannot determine whether the influence of the Brînzeni group decreased with distance.

Valentin Dergachev $(1980,133)$ wrote “...the most intense cultural and trade connections of the Volhynian tribes with the Brînzeni people [...] numerous items from Volhynian flint...”. According to B. Balcer $(1981,97 ; 1983)$ the presence of imported flint materials may reflect the intensity of contacts between different cultural groups. However, it is currently difficult to assess the importance of products from Volhynian raw material in the CII TC groups from Eastern Volhynia. In the case of the Brînzeni group, objects from this raw material are assigned an important role in the economy (Markevich 1981). In the FBC, due to the exchange of raw Volhynian flint, TC features are sometimes identified in areas far away from area TC (Rybicka 2017). It can be assumed that as a result of direct contacts related to the exchange of Volhynian flint between the groups inhabiting Eastern and Western Volhynia, the influence from the Brînzeni group reached the Ostrog region, while the FBC influence was felt in Eastern Volhynia (Korzivka-Selysko: Kruts and Ryzhov 2000, 97).

To conclude, the archaeological data do not give any reasons for total acceptance of the hypothesis about the migration of Brînzeni group communities from the south to East Volhynia. However, the presence of Volhynian raw material in collections from Brînzeni settlements in their homeland emphasizes the importance of material exchange. Such activities may relate to the spread of features of the Brînzeni group from the south to the 
north, and the appearance of imitations of ceramics and anthropomorphic figures from this group in the region of Ostrog (Verteletskiy 2016).

\section{$\mathrm{FBC}$ in the territory of Western Ukraine $(3700 / 3600-3000 / 2900$ BC)}

The study of the FBC in Western Ukraine allowed for the definition of the border of the eastern range of the culture (Fig. 1: B; 2: B; Hawinskyj et al. 2013; Gavinskiy 2009; 2013; Gavinskiy and Pasterkevich 2016). In Western Volhynia, the range of mobile settlement is marked by Styr River (Fig. 1: B; Rybicka 2017), whereas the remains of settlement of this culture identified in the area of Ostrog or Dubno do not confirm the permanent habitation of the FBC; however, the findings might be treated as the effect of mutual and direct contact with the TC (Rybicka 2017). It is difficult to determine the culture's southern range. The southeastern border might be set by the upper Dniester in the region of Zhuravno (Harmatowa et al. 2013). The boundary is defined by the settlement in Kotoryny, situated by the upper Dniester (Hawinskyj et al. 2013; Król 2019), with origins dating back to 37003600 BC (Fig. 2: B). The ornamental style of the ceramics refers to early stages of the eastern group of this culture (Czerniak and Kośko 1993; Grygiel 2016). Recently, some analogical materials have been distinguished in the Rzeszów-Przemyśl loess areas (Rybicka 2016a; Sieradzka and Głowacz 2017).

The information concerning the existence of a multi-phase settlement in Kotoryny until the period around 3300/3100 BC (Fig. 2: B) is based upon radiocarbon dating. Settlements like Vynnyky-Lysivka (Gavinskiy 2013; Diachenko et al. 2019; Rybicka et al. 2019), Lezhnitsa, site Czub (Rybicka et al. 2019), and stage II of the settlement in Zimne (Peleshchishin 2004; Rybicka et al. 2019) represent the youngest stage of the FBC in Ukraine. It is characterized by a conservative style of ceramics. The collections do not include many examples with decorations suggesting younger stages of the eastern and southeastern group of the FBC, such as broad decorations made with cord or channel ornamentation (Kośko 1981; Rybicka et al. 2014). The basic ornamentation motifs are simple decorations characteristic for early stages of the eastern group (Fig. 3: 2, 10; 4: 8), with a minor role of features of the southeastern group (Fig. 4: 1-5; 5: 3-5), neighbouring with the oecumene of the Western Ukrainian type of FBC.

Volhynian flint was the primary type used by the communities in the above-mentioned region, both in eastern Roztoche (Sobkowiak-Tabaka 2019) and by the upper Dniester (Konopla 2013), whereas the role of western materials like Świeciechów flint was minor, and could have been imported in the younger stages of the discussed culture (Konopla 2019).

The limited presence of stylistic features typical for the southeastern FBC group, along with the flint materials predominating in this region, show that communities residing in the region between the upper Dniester and upper Bug had not been in constant contact with the FBC communities living in the western regions (Rybicka et al. 2019). An interesting 

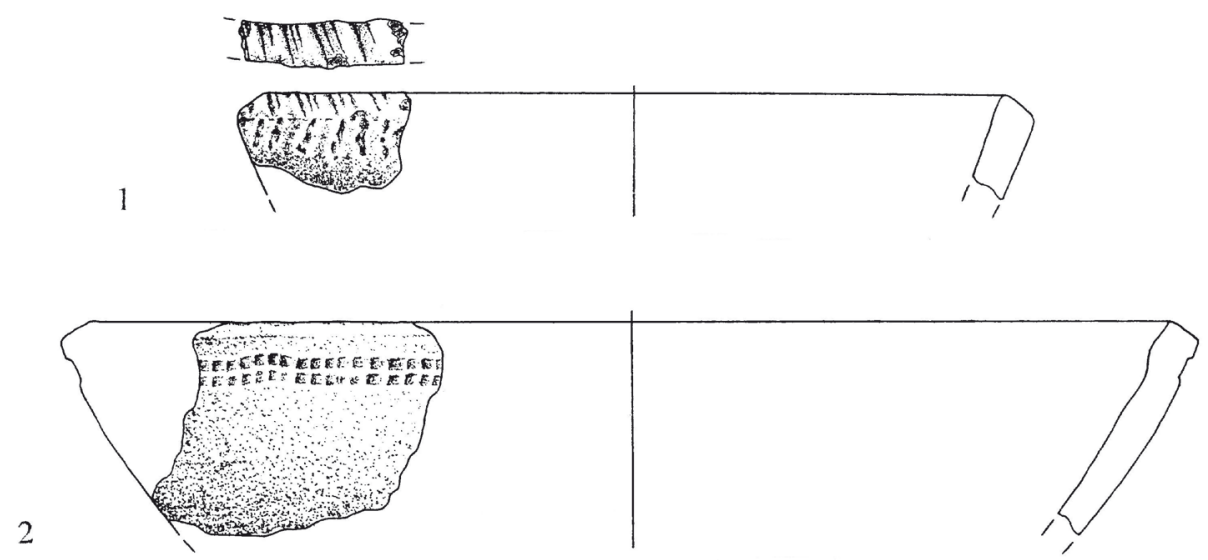

3
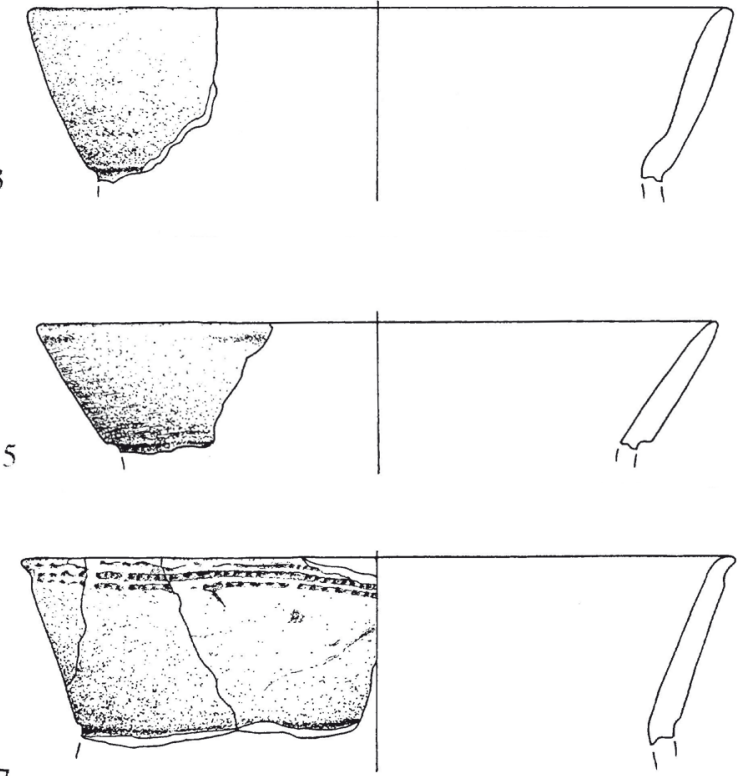

7

6

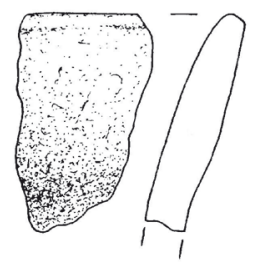

8

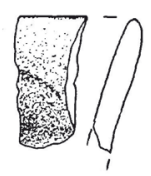

9
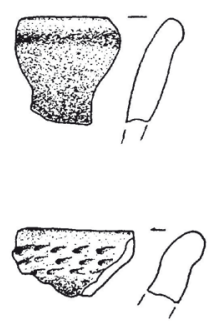

10

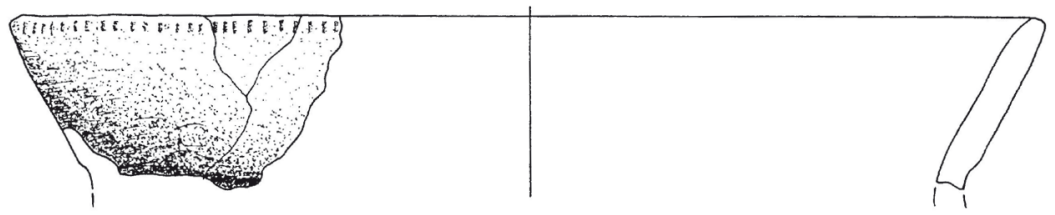

Fig. 3. Lezhnitsa, site Czub, Ivanychi raion. Funnel Beaker culture ceramics (acc. to Rybicka et. al. 2019) 

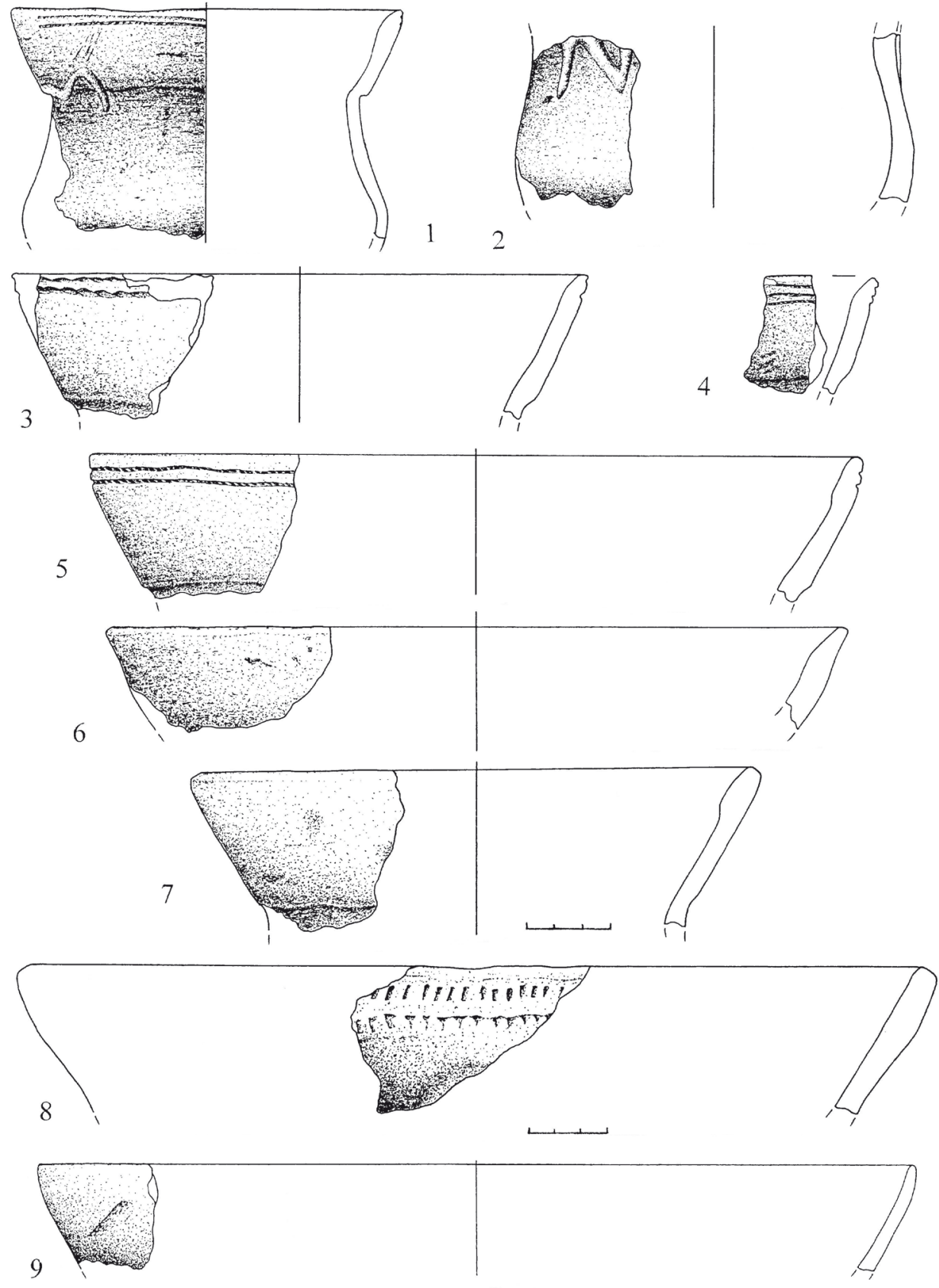

Fig. 4. Lezhnitsa, site Czub, Ivanychi raion. Funnel Beaker culture ceramics (acc. to Rybicka et. al. 2019) 

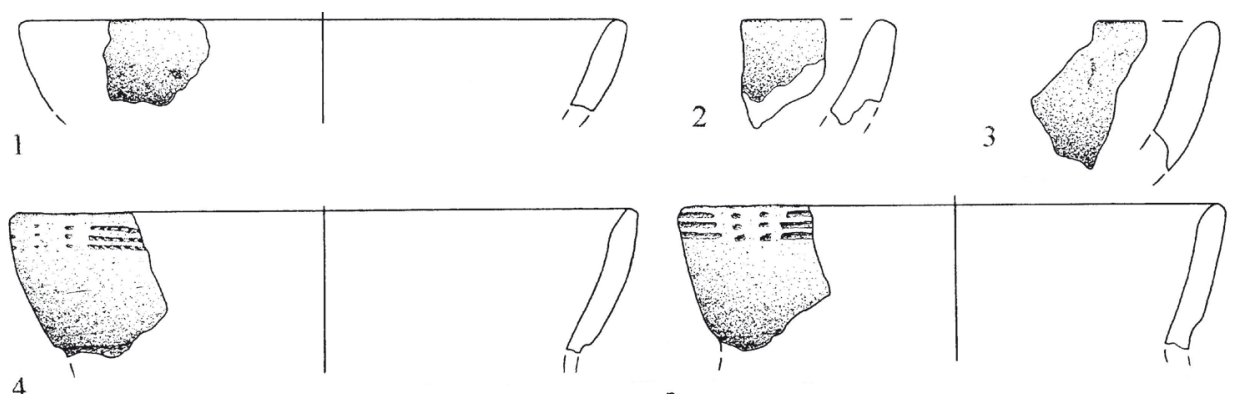

5
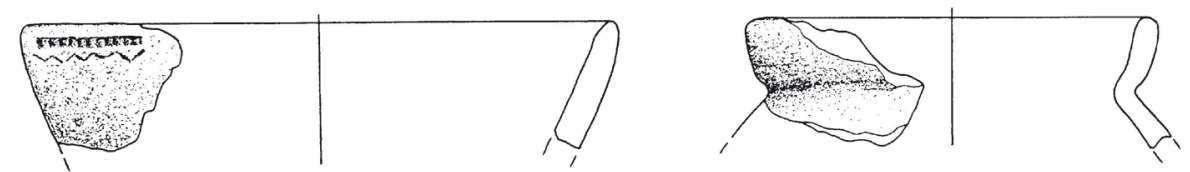

6

7
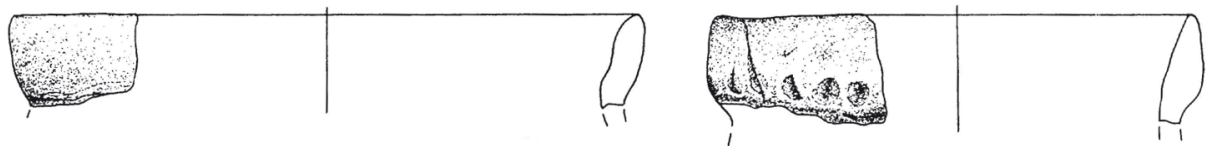

8

9

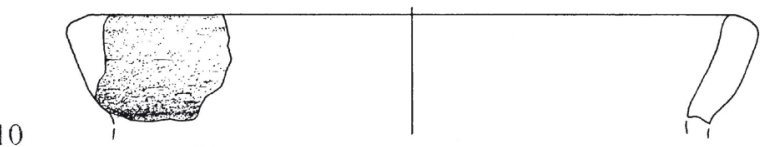

11

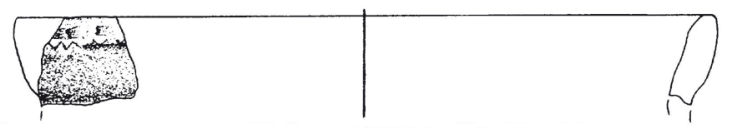

12
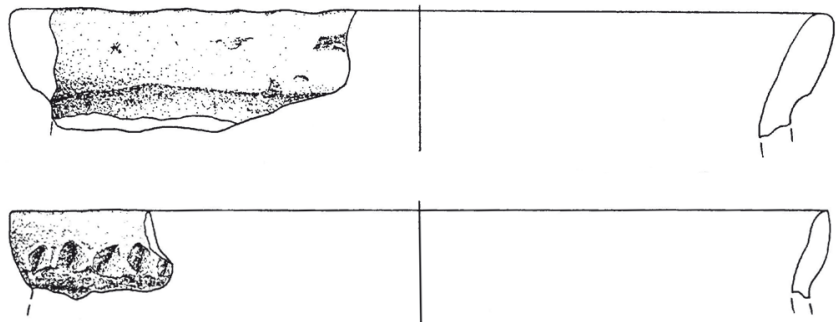

13

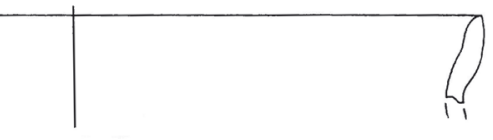

Fig. 5. Lezhnitsa, site Czub, Ivanychi raion. Funnel Beaker culture ceramics (acc. to Rybicka et. al. 2019) 
fact is that, despite the small distance from the reserves of Volhynian flint (about $80 \mathrm{~km}$ ), the inhabitants of a settlement in Vynnyky, site Lysivka, were very economical with their use of this material (Sobkowiak-Tabaka 2019).

From the very beginning, the groups of the FBC from west Ukraine maintained relationships with communities of the $\mathrm{TC}$, as reflected in the imports of tableware ceramics identified in the early stages of settlements in both Kotoryny (Hawinskyj et al. 2013) and Zimne (Peleshchishin 2004), dated to the period between 3650-3400 BC (Fig. 1: B; 2: B; Rybicka et al. 2019), and in the later stage represented by settlements like Rudniki (Konopla and Gavinskiy 2013), Małe Grzybowice (Gavinskiy 2009), Lezhnitsa, site Czub (Rybicka et al. 2019), and Vynnyky, site Lysivka (Gavinskiy 2013; Diachenko et al. 2019; Rybicka et al. 2019).

Within the collections of the three aforementioned settlements, there were some examples following the technologies (Fig. 6; Rybicka et al. 2018; Diachenko et al. 2019) and style (Rybicka et al. 2019) of ceramics of the TC ( $c f$. Rauba-Bukowska 2019; Rybicka 2015; 2016b). Their chronology corresponds to stage II of Gródek nad Bugiem and the settlement in Zimne (Rybicka et al. 2019). Similar to how the CII stage of the TC in Western Volhynia adapted the patterns of Funnel Beaker technologies for making kitchenware ceramics (Rybicka 2017), the communities living in the presented settlements adopted some features of the TC (Diachenko et al. 2019; Rybicka et al. 2019).

In western Ukraine, most of the known permanent settlements of the FBC were situated in the high situated flat areas (e.g. Kotoryny, Grodzisko III, Trostianets, Lezhnitsa, Vynnyky-Lysivka, Mali Hrybovychi, Zimne; Diachenko et al. 2019; Hawinskyj et al. 2013; Gavinskiy and Pasterkevich 2016; Rybicka et al. 2018; Rybicka et al. 2019; Gavinskiy 2009; 2013; Konopla and Gavinskiy 2013; Peleshchishin 2004). Therefore, their location is similar to the settlements of the Brînzeni and Gordineşti groups (Król 2019). The areas suitable for settlement were not larger than 4 hectares (Vynnyky-Lysivka). The settlements themselves were not large. It is not possible to say how were they constructed or how many houses were functioning at any one time. The remains of houses were identified in the form of clusters of daub. They are not equivalent with the construction features of the Brînzeni group (Markevich 1981). Moreover, the households were much different from the ones characteristic for the TC ( $c f$. Markevich 1981; Rybicka et al. 2018; Diachenko et al. 2019). Currently, it is not possible to describe the dynamics of changes in the manner of planning the settlements of the FBC. It is difficult to tell whether the intensification of relations between the FBC and the TC resulted in changes in agricultural and settlement systems of the FBC. According to A. Sady (2019), we may observe much similarity in the range of cultivated plants between the FBC and the TC, with the predominance of Triticum dicoccon, whereas Triticum monococcum is only an additive in sowing emmer wheat and does not form the basis for monocultural cultivation. Based on available data, it is impossible to describe, both in case of the FBC and the TC (Markevich 1981; Zabilska-Kunek 2013), the agricultural practices for cultivation and farming (Kruk 1980, 326-333) or 

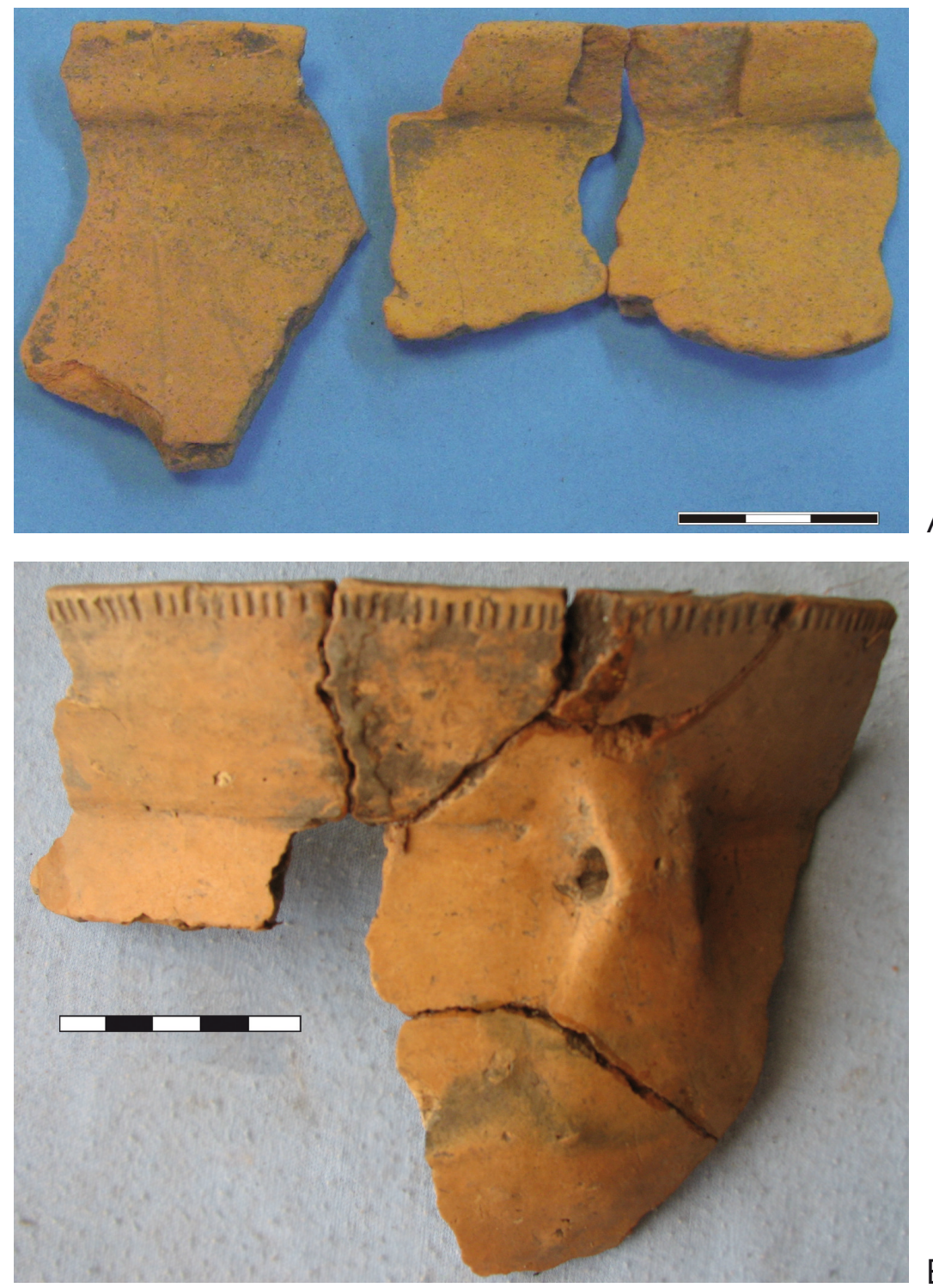

B

Fig. 6. Lezhnitsa, site Czub, Ivanychi raion.

Ceramics with Funnel Beaker culture (A) and Tripolye culture features (B) (acc. to Rybicka et al. 2019)

which animals were intended for consumption. The lack of data that would allow for comparison of changes between the agricultural and settlement systems hampers the description of mutual relations between the two cultures. 


\section{CONCLUSIONS}

\section{Is it possible to observe two parallel processes, gradual "Tripolization" of the FBC and "Beakerization" of the TC in western Ukraine?}

Some researchers have connected the first process with Bug communities of the FBC (Kośko 1981; Jastrzębski 1989). Intensification and diversity in relations between the two cultures may be observed in the Volhynian borderlands, where Volhynian flint was an accelerant (Rybicka 2017, 148-151). On the basis of available data, it is suggested that in the early stage of CII, dated to 3500-3350 BC, there were vessels of the FBC made with TC kitchenware technology, and a small collection of TC kitchenware made of clay weakened with fire clay (Fig. 2A; Novomalin-Podobanka; Rybicka 2017). Between 3300-3100 BC, there was a change in the production of everyday-use vessels of the TC (Rybicka 2016b). In case of Vynnyky, site Lisivka, and Lezhnitsa, site Czub - representing the end of the $4^{\text {th }}$ millennium BC - there appeared FBC ceramics made in a method similar to the technology of TC tableware (Rybicka et al. 2019). The available sources prove the process of "Tripolization" of FBC and "Beakerisation" of TC vessels in Western Volhynia (Pasterkiewicz et al. 2013; Rybicka 2017, 151; Rybicka et al. 2019).

To sum up, research conducted in recent years in Western Ukraine regarding the FBC and TC showed not only how strong were the relationships between their communities, but also what problems should be analyzed in the future (e.g. technology of flint-tool production, settlement patterns, features of the natural environment).

The article was written as part of the project NCN Opus 8 UMO 2014/15/B/HS3/02486 "Between The East and the West. Dynamics of Social Changes from the Eastern Carpathians to the Dnieper in the 4 th - beginning of the of 3rd Millennium BC".

\section{References}

Balcer B. 1981. Związki między kulturą pucharów lejkowatych (KPL) a kulturą trypolską (KT) na podstawie materiałów krzemiennych. In T. Wiślański (ed.), Kultura pucharów lejkowatych w Polsce (studia i materiały). Poznań: Polska Akademia Nauk, Oddział w Poznaniu - Leszczyńskie Towarzystwo Kulturalne, 82-91.

Balcer B. 1983. Wytwórczość narzędzi krzemiennych $w$ neolicie ziem Polski. Wrocław, Warszawa, Kraków: Zakład Narodowy im. Ossolińskich.

Bardeckiy A. and Verteltskiy D. 2019. Rozkopky ukriplenogo poselennia trypiliskoyi kultury etapu CII Myrogoscha-15 na Rivnenschyni. In: Yu.V. Boltryk (ed.), Arkheolohichni doslidzhennia v Ukraini 2017 roku. Kyiv: Institut Arkheologii NANU, 215-218.

Czerniak L. and Kośko A. 1993. Z badań nad genezq rozwoju i systematykq̨ kultury pucharów lejkowatych na Kujawach. Poznań: Uniwersytet im. Adama Mickiewicza w Poznaniu. 
Dergachev V. A. 1980. Pamiatniki pozdnego Tripolya. Kishinev: Shtiintsa.

Diachenko A. 2019. The Late Tripolye: spatio-demographic frames for culture change. In A. Diachenko, M. Rybicka, D. Król and G. Sîrbu (eds), Between the East and the West. Dynamic of Social Changes from the Eastern Carpathians to the Dnieper in the 4th - beginning of 3rd Millennium BC (Preliminary study). Rzeszów: Wydawnictwo Uniwersytetu Rzeszowskiego, 231-242.

Diachenko A. and Kirilenko A. 2016. Pozdneye Tripolye Zapadnoy Volini: sostoyaniye istochnikov i kratkiy obzor khronologicheskikh skhem. In A. Diaczenko, D. Król, A. Kyrylenko, M. Rybicka and D. Werteletski, Nowomalin-Podobanka i Kurgany-Dubova. Osiedla kultury trypolskiej na zachodnim Wolyniu. Rzeszów: Instytut Archeologii UR, Wydawnictwo Zimowit, 125-132.

Diachenko A. and Rybicka M. 2019. Volhynian flint and the trans-regional networks of the Funnel Beaker populations. In A. Diachenko, M. Rybicka, D. Król and G. Sîrbu (eds), Between the East and the West. Dynamic of Social Changes from the Eastern Carpathians to the Dnieper in the 4th - beginning of 3rd Millennium BC (Preliminary study). Rzeszów: Wydawnictwo Uniwersytetu Rzeszowskiego, 179-196.

Diachenko A., Rybicka M., Hawinskyj A., Król D and Sîrbu G. 2019. New excavations in Vynnyky and the issue of the Funnel Beaker culture - Tripolye frontier. In A. Diachenko, M. Rybicka, D. Król and G. Sîrbu (eds), Between the East and the West. Dynamic of Social Changes from the Eastern Carpathians to the Dnieper in the 4th - beginning of 3rd Millennium BC (preliminary study). Rzeszów: Wydawnictwo Uniwersytetu Rzeszowskiego, 17-30.

Diachenko A., Rybicka M., Król D. and Sîrbu G. (eds.) 2019. Between the East and the West. Dynamic of Social Changes from the Eastern Carpathians to the Dnieper in the 4th-beginning of 3 rd Millennium BC (Preliminary study). Rzeszów: Wydawnictwo Uniwersytetu Rzeszowskiego.

Diaczenko A., Król D., Kyrylenko A., Rybicka M. and Werteletski D. 2016. Nowomalin-Podobanka i Kurgany Dubowa. Osiedla kultury trypolskiej na zachodnim Wolyniu. Rzeszów: Instytut Archeologii UR, Wydawnictwo Zimowit.

Dobrzyński M. and Piątkowska K. 2015. Krzemienne materiały pracowniane z pierwszego sezonu badań na stanowisku Nowomalin-Podobanka, rejon Ostrog, obwód Rownieński. In Davni maysterni ta virobnitstvo u Vislo-Dniprovskomu regioni (= Naukovi Studii Vipusk 8). Zheshiv, Vinniki, Lviv: Istoriko-Kraeznavchiy Muzey m. Vinniki, 76-95.

Gavinskiy A. (= Hawinskyj A.) 2009. Poselennia kulturi liychastogo posudu v Malikh Gribovichakh. Materiali i doslidzhennia z arkheologii Prikarpattia i Volini 13, 172-197.

Gavinskiy A. (= Hawinskyj A.) 2013. Poselennia kulturi liychastikh kubkiv Vinniki-Lisivka. In A. Pozikhovski, J. Rogoziński and M. Rybicka (eds), Na pograniczu kultury pucharów lejkowatych i kultury trypolskiej (= Collectio Archaeologica Ressoviensis 26). Rzeszów: Instytut Archeologii UR, Wydawnictwo Mitel, 55-74.

Gavinskiy A. and Pasterkevich V. (= Hawinskyj A. and Pasterkiewicz W.) 2016. Arkheologichni pamiatniki kulturi liychastogo posudu na teritorii Ukraini. Lviv.

Grygiel R. 2008. Neolit i początki epoki brązu w rejonie Brześcia Kujawskiego i Ostonek, 2. Środkowy neolit. Grupa brzesko-kujawska kultury lendzielskiej. Łódź: Fundacja Imienia Konrada Jażdżewskiego, Muzeum Archeologiczne i Etnograficzne w Łodzi. 
Grygiel R. 2016. Podstawy źródłowe. Charakterystyka obiektów i materiałów ze stanowisk badanych wykopaliskowo w rejonie Brześcia Kujawskiego i Osłonek. In R. Grygiel, T. Łapińska and P. Papiernik (eds), Neolit i początki epoki brązu w rejonie Brześcia Kujawskiego i Osłonek. III. Środkowy i późny neolit. Kultura pucharów lejkowatych. Łódź: Fundacja Badań Archeologicznych imienia profesora Konrada Jażdżewskiego, Muzeum Archeologiczne i Etnograficzne w Łodzi, 17-596.

Harmatowa K., Machnik J. and Rybicka M. (eds) 2013. Natural environment and man on the upper Dniester - region of the Halyč-Bukačivci basin - in prehistory and early medieval period (= Prace Komisji Prehistorii Karpat PAU 6). Kraków: Polska Akademia Umiejętności.

Harper T. K. 2012. Sustaining Talianki: a model of Eneolithic subsistence economics at a Giant-settlement of the Western Tripolye Culture, Ukraine. SUNY at Buffalo, (M.A Thesis).

Harper T. K. 2013. The effect of climate variability on population dynamics of the Cucuteni-Tripolye cultural complex and the rise of the Western Tripolye giant-settlements. Chronika 3, 28-46.

Harper T. K. 2017. Demography and climate in Late Eneolithic Ukraine, Moldova, and Romania: multiproxy evidence and pollen-based regional corroboration. Journal of Archeological Science Reports, https://doi.org/10.1016/j.jasrep.2017.06.01.

Harper T., Diachenko A., Rassamakin Y. and Kennett D. J. 2019. Ecological dimenssions of population dynamics and subsistence in Neo-Eneolithic Eastern Europe. Journal of Anthropological Archaeology 53, 92-101, https://doi.org/10.1016/j.jaa.2018.11.006.

Hawinskyj A., Pasterkiewicz W. and Rybicka M. 2013. Kotoryny, rej. Żydaczów, stan. Grodzisko III. Osadnictwo z okresu neolitu. In K. Harmatowa, J. Machnik and M. Rybicka (eds), Natural environment and man on the upper Dniester - region of the Halyč-Bukačivci basin - in prehistory and early medieval period (= Prace Komisji Prehistorii Karpat PAU 6). Kraków: Polska Akademia Umiejętności, 169-284.

Jastrzębski S. 1989. Kultura Cucuteni-Trypole i jej osadnictwo na Wyżynie Wołyńskiej. Lublin: Wydawnictwo Uniwersytetu Marii Curie-Skłodowskiej.

Kobyliński Z. 1988. Struktury osadnicze na ziemiach polskich u schyłku starożytności i $w$ początkach wczesnego średniowiecza. Wrocław: Ossolineum.

Konopla V. 1998. Klasifikatsiya kremianoi surovini zakhodu Ukraini. Naukovi zapiski Lvivskogo universitetu $7,139-157$.

Konopla V. 2013. Virobi z kremeniu pamiatki Kotorini III. In K. Harmatowa, J. Machnik and M. Rybicka (eds), Natural environment and man on the upper Dniester - region of the HalyčBukačivci basin - in prehistory and early medieval period (= Prace Komisji Prehistorii Karpat PAU 6). Kraków: Polska Akademia Umiejętności, 285-301.

Konopla V. 2019. Virobi z kremeniu poselennia Lezhnitsa - “Chub”. In M. Rybicka, A. Hawinskyj and W. Pasterkiewicz, Leżnica, stanowisko Czub - osiedle kultury pucharów lejkowatych na zachodnim Wolyniu z analiza zabytków krzemiennych autorstwa Witalija Konopli. Rzeszów: Wydawnictwo Uniwersytetu Rzeszowskiego, 67-88.

Konopla V. and Gavinskiy A. 2013. Poselennia kulturi liychastogo posudu Rudniki v pivnichno-skhidnomu Peredkarpatti. In A. Pozikhovski, J. Rogoziński and M. Rybicka (eds), Na pograniczu 
kultury pucharów lejkowatych i kultury trypolskiej (= Collectio Archaeologica Ressoviensis 26). Rzeszów: Instytut Archeologii UR, Wydawnictwo Mitel, 37-54.

Kośko A. 1981. Udziat południowo-wschodnioeuropejskich wzorców kulturowych $w$ rozwoju niżowych spoleczeństw kultury pucharów lejkowatych. Grupa mątewska. (= Seria archeologiczna 19). Poznań: Uniwersytet im. Adama Mickiewicza w Poznaniu.

Król D. 2019. Eneolithic settlements of the Funnel Beaker culture and the Late Tripolye culture of the Western Ukraine and Northern Moldova in the topo-hydrological contexts. A comparative study. In A. Diachenko, M. Rybicka, D. Król and G. Sirbu (eds), Between the East and the West. Dynamic of Social Changes from the Eastern Carpathians to the Dnieper in the 4thbeginning of 3rd Millennium BC (Preliminary study). Rzeszów: Wydawnictwo Uniwersytetu Rzeszowskiego, 217-230.

Kruc V. (Kruts V.) 1994. „Osiedla-giganty” oraz niektóre problemy demograficzne kultury trypolskiej. Archeologia Polski 39, 7-30.

Kruk J. 1980. Gospodarka $w$ Polsce południowo-wschodniej $w$ V-III tysiącleciu p.n.e. Warszawa: Zakład Narodowy im. Ossolińskich.

Kruk J., Alexandrowicz S. W., Milisauskas S. and Śnieszko Z. 1996. Osadnictwo i zmiany środowiska naturalnego wyżyn lessowych. Studium archeologiczne i paleogeograficzne nad neolitem $w$ dorzeczu Nidzicy. Kraków: Instytut Archeologii i Etnologii PAN.

Kruk J. and Milisauskas S. 1999. Rozkwit i upadek spoleczeństw rolniczych neolitu. Kraków: Instytut Archeologii i Etnologii PAN.

Kruts V. and Ryzhov S. (Rizhov S.) 2000. Tripolye culture in Volhynia (Gorodsk-Volhynian group). Baltic-Pontic Studies 9, 86-110.

Levi-Strauss C. 1979. Drogi masek. Łódź: Wydawnictwo Łódzkie.

Makohonienko M. 2011. Przyrodnicze aspekty pradziejowych i wczesnohistorycznych szlaków tranzytowych bałtycko-pontyjskiej przestrzeni kulturowej. In M. Ignaczak, A. Kośko and M. Szmyt (eds), Między Battykiem a Morzem Czarnym. Szlaki międzymorza IV-I tys. przed. Chr. (= Archaeologia Bimaris 4). Poznań: Wydawnictwo Poznańskie, 21-6o.

Markevich V. I. 1981. Pozdnetripolskiye plemena cevernoy Moldavii. Kishinev: Shtipnitsa.

Movsha T. 1982. Periodizatsiya i khronologiya seredniogo ta pizniogo Tripilia. Arkheologiya 5, 3-24.

Movsha T. 1985. Vzayemovidnosini Tripillia-Kukuteni z sinkhronnimi kulturami Tsentralnoi Evropi. Arkheologiya 51, 22-31.

Pasterkiewicz W., Pozikhovski A., Rybicka M. and Verteletskyi D. 2013. Z badań nad problematyką oddziaływań kręgu badeńskiego na wschodnie rejony Wyżyny Wołyńskiej. In A. Pozikhovski, J. Rogozinski and M. Rybicka (eds), Na pograniczu kultury pucharów lejkowatych i kultury trypolskiej (= Collectio Archaeologica Ressoviensis 26). Rzeszów: Instytut Archeologii UR, Wydawnictwo Mitel, 251-291.

Peleshchishin M. A. 2004. Eneolitichne poselennia Zimne v Zakhidniy Volini. Ternopil.

Pelisiak A. 2005. Pogranicze kultury trypolskiej i kultury pucharów lejkowatych. Stan badań. In A. Garbacz and M. Kuraś (eds), Kultura trypolska. Wybrane problemy. Stalowa Wola: $\mathrm{Mu}-$ zeum Regionalne w Stalowej Woli, 32-41. 
Pelisiak A. 2018. Centrum i peryferia osadnictwa $w$ neolicie i wczesnej epoce brązu na Podkarpaciu i we wschodniej części polskich Karpat (= Collectio Archaeologica Ressoviensis 38). Rzeszów: Wydawnictwo Uniwersytetu Rzeszowskiego, Oficyna Wydawnicza „Zimowit”.

Pelisiak A., Rybicka M. and Ralska-Jasiewiczowa M. 2006. From the Mesolithic to modern times. Settlement organization and economy recorded in annually laminated sediments of the Lake Gościąż (Central Poland) (= Collectio Archaeologica Ressoviensis 2). Rzeszów: Instytut Archeologii UR, Wydawnictwo Mitel.

Pozikhovskyj O. 2019a. Eneolithic pottery kiln from Ostrog in western Ukraine. In A. Diachenko, M. Rybicka, D. Król and G. Sîrbu (eds), Between the East and the West. Dynamic of Social Changes from the Eastern Carpathians to the Dnieper in the 4th - beginning of 3rd Millennium BC (preliminary study). Rzeszów: Wydawnictwo Uniwersytetu Rzeszowskiego, 9-16.

Pozikhovskyj O. 2019b. An attempt to define a chronology of the late Tripolye settlement near the village of Holyshiv in the western Volhynia. In A. Diachenko, M. Rybicka, D. Król and G. Sîrbu (eds), Between the East and the West. Dynamic of Social Changes from the Eastern Carpathians to the Dnieper in the 4th - beginning of 3rd Millennium BC (preliminary study). Rzeszów: Wydawnictwo Uniwersytetu Rzeszowskiego, 31-42.

Pozikhovskiy O. L. and Samoliuk V. O. 2008. Eneolitichniy krematsiyniy mogilnik v okolitsiakh Ostroga na Zakhidniy Volini. Arkheologiya 1(2008), 28-41.

Rauba-Bukowska A. 2019. Specialized analyses of ceramic vessels of the Funnel Beaker culture and the Tripolye culture from sites Kurgany-Dubova, Vynnyky-Zhupan, Mezhyrich, Vynnyky-Lysivka, and Gordineşti II--Stînca goală. In A. Diachenko, M. Rybicka, D. Król and G. Sîrbu (eds), Between the East and the West. Dynamic of Social Changes from the Eastern Carpathians to the Dnieper in the 4th - beginning of 3rd Millennium BC (preliminary study). Rzeszów: Wydawnictwo Uniwersytetu Rzeszowskiego, 133-144.

Rizhov S. M. 2007. Suchasniy stan vivchennia kulturnoistorichnoi spilnosti Kukuteni-Tripillia. In Yu.Ya. Rassamakin and S. M. Rizhov (eds), Oleg Olzhich. Arhkeologiya. Kiiv: Vidavnitstvo im. Oleni Teligi, 437-477.

Rybicka M. 2004. Kultura pucharów lejkowatych na Pojezierzu Gostynińskim. Chronologia, osadnictwo, gospodarka. Łęczyca: Muzeum w Łęczycy.

Rybicka M. 2015. Eastern peripheries of the Funnel Beaker culture. In A. Diachenko, F. Menotti, S. Ryzhov, K. Bunyatyan and S. Kadrow (eds), The Cucuteni-Tripolye cultural complex and its neighbours: Essays in memory of Volodymyr Kruts. Lviv: Astrolabe, 167-182.

Rybicka M. 2016a. Nowe dane w kwestii datowania kultury pucharów lejkowatych na Podgórzu Rzeszowskim. Materiaty i Sprawozdania Rzeszowskiego Ośrodka Archeologicznego 37, 69-83.

Rybicka M. 2016b. Ceramika o zachodniej lub południowo-zachodniej afiliacji. In A. Diaczenko, D. Król, A. Kyrylenko, M. Rybicka and D. Werteletski (eds), Nowomalin-Podobanka i Kurgany Dubowa. Osiedla kultury trypolskiej na zachodnim Wotyniu. Rzeszów: Instytut Archeologii UR, Wydawnictwo Zimowit, 101-118.

Rybicka M. 2017. Kultura trypolska - kultura pucharów lejkowatych. Natężenie kontaktów i ich chronologia (= Collectio Archaeologica Ressoviensis 37). Rzeszów: Wydawnictwo Uniwersytetu Rzeszowskiego i Wydawnictwo Zimowit. 
Rybicka M. and Diachenko A. 2016. New evidence regarding the Interactions between populations of the Funnel Beaker culture and Tripolye culture in western Ukraine. In C. Preoteasa and CiprianDorin Nicola (eds), Cucuteni culture within the European Neo-Eneolithic context. Piatra, Neamț: Neamț County Museum Complex, 679-699.

Rybicka M., Hawinskyi A., Król D. and Diachenko A. 2018. Eastern impulses in the eastern group of the Funnel Beaker culture. Prace i Materiały Muzeum Archeologicznego i Etnograficznego $w$ Łodzi. Seria Archeologiczna 47, 395-419.

Rybicka M., Hawinskyj A. and Pasterkiewicz W. 2019. Leżnica, stanowisko Czub - osiedle kultury pucharów lejkowatych na zachodnim Wolyniu z analizą zabytków krzemiennych autorstwa Witalija Konopli. Rzeszów: Wydawnictwo Uniwersytetu Rzeszowskiego.

Rybicka M., Król D. and Rogoziński J. 2014. Pawłosiów, stan 52, woj. podkarpackie. Osada kultury pucharów lejkowatych. In M. Rybicka (ed.), Wschodnie pogranicze grupy poludniowowschodniej kultury pucharów lejkowatych (= Collectio Archaeologica Ressoviensis 28). Rzeszów: Instytut Archeologii UR, Wydawnictwo Mitel, 67-256.

Sady A. 2019. Contribution to Studies on plant Economies of Neolithic Communities in Moldova and Ukraine. In A. Diachenko, M. Rybicka, D. Król and G. Sîrbu (eds), Between the East and the West. Dynamic of Social Changes from the Eastern Carpathians to the Dnieper in the 4 thbeginning of 3rd Millennium BC (preliminary study). Rzeszów: Wydawnictwo Uniwersytetu Rzeszowskiego, 145-156.

Sieradzka E. and Głowacz M. 2017. Materiały kultury pucharów lejkowatych ze stanowiska 31 w Skołoszowie, pow. jarosławski, woj. podkarpackie. In M. Rybicka (ed.), Wielokulturowe cmentarzysko $w$ Skołoszowie, stanowisko 7, pow. jarosławski w kontekście osadnictwa z neolitu i wczesnej epoki brazu we wschodniej części Podgórza Rzeszowskiego. Rzeszów: Instytut Archeologii UR, Wydawnictwo Zimowit, 71-105.

Sobkowiak-Tabaka I. 2019. Flint knapping industry of the Funnel Beaker culture population from the site Vynnyky-Lysivka, Lviv district (excavation season 2016). In A. Diachenko, M. Rybicka, D. Król and G. Sîrbu (eds), Between the East and the West. Dynamic of Social Changes from the Eastern Carpathians to the Dnieper in the 4th - beginning of 3rd Millennium BC (preliminary study). Rzeszów: Wydawnictwo Uniwersytetu Rzeszowskiego, 157-172.

Szmyt M. 2013. Late Neolithic landscapes one the Polish lowland: people, culture and economy in Kujawy - 4th and 3rd millennia BC (= Studien zur Archäologie in Ostmitteleuropa/Studia nad Pradziejami Europy Środkowej 12). Poznań, Bonn: Wydawnictwo Naukowe UAM, Dr Rudolf Habelt $\mathrm{GmbH}$.

Tkachuk T. 1998. Pokhodzheniya ta vidnosna khronologiya koshilovetskoy grupi. In V. Oliynik (ed.), Mizhnaroda konferentsiya "Tripilske poselennia Koshilivtsi-Oboz" (do 10o-richchia vidkrittia), Prikarpattia. Zalishchiki, 15-17.

Verteletskiy D. 2016. Keramika poseleniya Novomalin-Podobanka. In A. Diaczenko, D. Król, A. Kyrylenko, M. Rybicka and D. Werteletski, Nowomalin-Podobanka i Kurgany-Dubowa. Osiedla kultury trypolskiej na zachodnim Wolyniu. Rzeszów: Instytut Archeologii UR, Oficyna Wydawnicza „Zimowit”, 35-69. 
Verteletskyi D. 2019a. Pottery of Gordineşti group of the Tripolye culture from Vynnyky-Zhupan. Preliminary study. In: A. Diachenko, M. Rybicka, D. Król and G. Sîrbu (eds), Between the East and the West. Dynamic of Social Changes from the Eastern Carpathians to the Dnieper in the 4th - beginning of 3rd Millennium BC (preliminary study). Rzeszów: Wydawnictwo Uniwersytetu Rzeszowskiego, 43-90.

Verteletskyi D. 2019b. Pottery of Gordineşti group of the Tripolye culture from Zvenyachyn. Preliminary study. In A. Diachenko, M. Rybicka, D. Król and G. Sîrbu (eds), Between the East and the West. Dynamic of Social Changes from the Eastern Carpathians to the Dnieper in the 4th - beginning of 3rd Millennium BC (preliminary study). Rzeszów: Wydawnictwo Uniwersytetu Rzeszowskiego, 91-102.

Videiko M. Y. 200o. Trypolye and the Cultures of Central Europe. Facts and Character of interactions: 4200-2750 BC. Baltic-Pontic Studies 9, 13-68.

Videyko M. 2007. Tripilska kultura u evropeyskomu konteksti. In M. Gierlach and L. BakalarskaManturzewska (eds), Wspólnota dziedzictwa archeologicznego ziem Ukrainy i Polski. Materiały z konferencji zorganizowanej przez Ośrodek Ochrony Dziedzictwa Archeologicznego, Łańcut (26-28.X.2005 r.). Warszawa: Krajowy Ośrodek Badań i Dokumentacji Zabytków, 315-333.

Wacnik A. and Rybicka M. 2012. Palinologiczne fazy wzmożonej aktywności człowieka. Korelacja danych paleośrodowiskowych z wynikami badań archeologicznych. In: M. Rybicka and A. Wacnik (eds), The impact of prehistoric and Medieval societies on the natural environment of the Gostynin Lake District, central Poland (= Collectio Archaeologica Ressoviensis 19). Rzeszów: Wydawnictwo Mitel, 171-183.

Włodarczak P. 2006. Chronologia grupy południowo-wschodniej kultury pucharów lejkowatych $\mathrm{w}$ świetle dat radiowęglowych. In J. Libera and K. Tunia (eds), Idea megalityczna w obrządku pogrzebowym kultury pucharów lejkowatych. Lublin, Kraków: Instytut Archeologii UMCS, Instytut Archeologii i Etnologii PAN, 27-66.

Zabilska-Kunek M. 2013. Wstępne wyniki badań zwierzęcych szczątków kostnych ze stanowiska "Grodzisko" III w Kotorynach. In K. Harmatowa, J. Machnik and M. Rybicka (eds), Natural environment and man on the upper Dniester - region of the Halyč-Bukačivci basin - in prehistory and early medieval period (= Prace Komisji Prehistorii Karpat PAU 6). Kraków: Polska Akademia Umiejętności, 302-312. 
